\title{
NON-NATIVE ENGLISH SPEAKER TEACHER NARRATION OF NATIVISM
}

\author{
Muhammad Iqbal Ripo Putra, Citra Iswara, Dedi Irwan* \\ Program of English Education, Faculty of Language and Arts Education \\ IKIP PGRI, Pontianak, Indonesia \\ Master Program, Indonesia University of Education \\ Program of English Education, Faculty of Language and Arts Education \\ IKIP PGRI, Pontianak, Indonesia \\ Corresponding E-mail: dediirwanphd@gmail.com
}

\begin{abstract}
The $21^{\text {st }}$ century ELT world is trying to migrate into the more relevant notion of international English. This notion, supposedly, supports every English speaker of a different nation, background, and culture. However, the public preference in native speaker is still apparent. This study is aimed to explore one non-native English speaker teacher's experiences in teaching English along with a native English speaker teacher. This study employed narrative inquiry, the data gathered by interviews, and document analysis. The non-native English speaker teacher experiences several discriminations in the form of job division, job requirements, and even the wage difference. The public preference for native English speaker teachers is still apparent, looking at the growth of schools with native-speaker teachers.
\end{abstract}

Keywords: Non-Native English Speaker Teacher, Nativism In ELT, Narrative Inquiry.

\section{INTRODUCTION}

The $21^{\text {st }}$ century English language learning has been drifting from the old notion of nativism into international English. English is used widely all over the world, from the people of Englishspeaking backgrounds to the speaker of other language backgrounds. The notion of global English promotes denationalization, which means everyone who speaks the language can own the word. Nevertheless, the public opinion on learning English is still leaning toward nativism. It can be seen on the growth of schools and courses which hire Native English-Speaking Teacher (NEST) as part of their marketing. Sadly, 'native-teacher' does not always own a teaching qualification and training. The employment of this 'native-teacher' inevitably affects the local teacher, also referred to as the Non-Native English Speaker Teacher (NNEST). This study is aimed to unravel a story from a non-native English-speaking teacher's (NNEST) experiences and perspective when working with a native speaker teacher.

The native and non-native speakerism

One of the crucial parts of teaching is the teacher. However, the teacher's proficiency and familiarity with the language make the English native speaker much more preferred than a local teacher. The native speaker refers to the speaker whom English is L1 acquired during childhood, has a wide range of 
grammar which allow a spontaneous response, has a wide variety of language style and can be a good model for L2 learner (Davies, 2006). Even though the native speaker can be a good model for a language learner, a local teacher also gave advantages in teaching a foreign language. The following part will discuss the benefits and the detriment of both native speakers as a teacher and non-native speaker as a teacher.

\section{Native English speaker teacher}

The native speakerism in language teaching is much preferred due to the assumption that native speaker can be a good model for the learner. Supporting this statement, Ali (2014) in her study found that several English teachers in Malaysia sought native speaker as the only teaching model and standard for the language assessment, stressing, without the existence of native standard there will be difficulties in assessing the students' language achievement. Similarly, Quirk (1985) contended that the native speaker not only as 'authentic' language model but also as the protector of the language. The argument of native English as a standard form is grounded on the opposing argument of local English as the standard English. The supporters of native English argue that if the local English are allowed to develop, it will outgrow the native English and the possibility of the English speaker not understanding each other (McKay, 2009). The fondness of native English as the standard language is none other than its historical and political accuracy, it is the standard of how the language supposed to be achieved, and its clear rules make the assessment more comfortable to conduct.

In order to achieve such a standard, there is a need to employ the native speaker as the teacher. The native English speaker teacher are mostly seen as friendlier teacher, with broader range of vocabulary, language style, deeper cultural understanding, and oral skill, which can be very helpful for the learner to relied on and to imitate (Mahboob, 2003; Lasagabaster \& Sierra, 2005; Wu \& Ke, 2009). Native speakers are often seen as a reliable source of teaching as they have more natural oral skills and can explain the context of the text better than the local teacher. However, the native speaker pronunciation can also be challenging to be understood by L2 learners (Lasagabaster \& Sierra, 2005). The cultural differences also make the native teacher difficult in building similar references as the learner and often fail to explain the regular feature of the language (Lasagabaster \& Sierra, 2005; Han, 2005). Although a native English speaker teacher capable of being a language model to the learner, they cannot relate to the learners understanding culturally. Therefore, the native teacher cannot check whether they and the students share mutual understanding.

\section{Non-native English speaker teacher}

The local teacher, or the nonnative English speaker teacher, unlike the native teacher, shares the same cultural understanding with the learners. The local teacher who owns a similar background as the learner can develop learners' understanding by using examples that the learners can relate on. In addition, as nonnative learners themselves, the local teacher able to explain more complex language grammar and structure better than the native teacher (Walkinshaw \& Oanh, 2014; Mahboob, 2003; McKay, 2003). As the native teachers have excellent oral skills and lacking in language rules, the contrary happened to the local teacher. A local teacher has better language rules knowledge but lacking in oral skills (Mahboob, 2003). Because of that, the local teacher often discredited and seen as less capable than the native teacher in teaching English.

The local teachers are often discriminated against in their workplace because they are not 'white' enough to teach English. The discrimination often 
happened because the teacher is not Caucasian regardless of their L1 is English (Sharifian, 2009; Holliday, 2006). Even if they work together in the same institution, the local teacher will be treated differently compared to the native teacher. The local teacher will teach more linguistics courses than the native teacher, and the native teacher is the only one that can teach the language skills (Manara, 2013). Even though the local teacher has some advantage in teaching English as a foreign or second language to the learners, they still face many difficulties in achieving the same position as the native teacher.

\section{Challenges faced by non-native teacher}

Thepre-existing discrimination in the workplace is just one example from many challenges the NNEST faced throughout their professional journey as an English teacher. Braine (2010, pp. 73 79) explain how the NNEST deal with challenges both extrinsically and intrinsically.

Thepre-existing discrimination in the workplace is just one example from many challenges the NNEST faced throughout their professional journey as an English teacher. Braine (2010, pp. 7379) explain how the NNEST deal with challenges both extrinsically and intrinsically. Extrinsically speaking, the hiring rate for NNEST in higher education level is relatively low compared to, obviously, the NEST. It can be seen in several studies where the majority of the school administrators consider nativism as the essential aspect of hiring a teacher (Alenazi, 2014; Clark \& Paran, 2007). Besides that, the employability of a NEST is often guided by the 'white-native fallacy'; the white Caucasian people are the native English speaker; the rest is not. These cases are often found in Asia; the white teacher from eastern Europe will have a higher employment rate compared to Asian-American teachers, regardless of the teacher's L1 (Braine, 2010; Sharifian, 2009). What is worse than competing against the teacher's L1 background, is competing against the skin color. Asian's reference in hiring the 'native' teacher has deviated far from the primary purpose of giving a good language model. It will burden the local teachers in their professionalism as a teacher for competing against something that is out of their control, even though they have a better qualification to be an English teacher.

In addition to that, from a fundamental point of view, the NNEST stressed their own local accent and language proficiency. As describe by Braine (2010), the local teachers are concerned with their accent when they speak in English. As a result, the NNEST habitually taught English in their native language. This phenomenon also leads to the teachers declining English proficiency and lower self-esteem (Braine, 2010; Rajagopalan 2005). Moreover, the NNEST is often stressed out from jobrelated issues, fear being underprepared, fear being undervalued, and having difficulty in career advancement (Rajagopalan, 2005). After being always compared to the native teacher, the local teacher develops anxiety over their professional status. Some teachers might be thinking that they will never be good enough to be an English teacher, which will also lead them to cease to advance themselves as a teacher and as a professional.

Overall, the struggles that the NNEST faced came from what society demand from an English teacher. The need for a good language model has promoted the NEST existence to be higher than the NNEST. An authentic model is undeniably useful for language learning; thus, the native teacher can fill in the NNEST's incapacity. However, the native speaker fallacy has alienated the NEST from their position as an English teacher. The so-called native teacher does not have to be from an English-speaking country, as long as they are white, they can be 
'native' teacher. This is, of course, a considerable disadvantage for the NNEST. The fact that they did not grow up in the English environment and did not look like a Caucasian will make them seem less prominent than the "whitenative' teacher, regardless of their English proficiency and pedagogical competence.

The school's favour towards the NEST can be seen as a discrediting act for NNEST, which also affects teacher professionalism. There are only a few studies related to the native speakerism, especially in the context of teacher professionalism in Indonesia. Therefore, this study is aimed to explore a NonNative English Speaker Teacher's (NNEST) understanding of his position working alongside a Native English Speaker Teacher (NEST). This study holds a positive attitude to gain insight into the relationship between NEST and NNEST from a NNEST point of view and can be used to promote NNEST professional development.

\section{METHOD}

The purpose of this study is to explore the teacher's personal story as a non-native English-speaking teacher; therefore, this study employed a narrative inquiry. Narrative inquiry is a data collecting method that allows the researcher to explore the participant's life story or experience and how they make meaning out of it (Creswell, 2012; Meriam, 2009; Mills \& Gay, 2016). Narrative inquiry does not solely focus on the research subject's narration of their experiences on the issue, but also on the meaning behind those experiences to the subject. Likewise, Cochran-Smith \& Lytle (2009) insist that narrative inquiry has blurred the line between theory and practice by exploring how the insiders theorize and understand their involvement from the inside. Narrative inquiry is the most suitable research design to nature of this study, which is aimed to reveal a nonnative English-speaking teacher's experiences teaching alongside a native teacher, and how he interprets the meaning behind every experience.

The subject of this study is an English teacher in one language school in West Kalimantan. Bruce (pseudonym) had been teaching in the school for three years soon after graduating from his bachelor's degree. Bruce earned his degree in teaching English as a foreign language and also graduated from the same language school he used to work for. During his service as a teacher, he has been teaching various students with various backgrounds, skills, and purposes. Bruce taught conversation class, IELTS preparation class, and general English class in his school. Bruce became the subject of this study by presenting his narration as a non-native English teacher in a language school that is shadowed by nativism.

In order to explore the teacher's narration on his experience as a nonnative English-speaking teacher, this study used a semi-structured narrative interview as the primary data. The semistructured interview deemed to be useful in obtaining the information related to the main question/issue without being strictly ordered like the structured interview (Muylaert et al., 2014). The interview was guided loosely by several questions related to the teacher's opinion on his position as NNEST, experience working with NNEST, and struggles in his professional development. The interviews were conducted in three times. To support the primary data, document analysis employed as the secondary data. The document that was analyzed was two promotional brochure which was gathered from the school official Facebook page. The data was validated through triangulation between the primary and secondary data and member checking, where the interviewee was asked to check whether the report represents what he intended to say. 
The finding of this study will be presented in the form of a story. Restory, according to Creswell (2012), is a process where the data were analyzed according to its plot, time, place, and another major element from the issues, then later to be told in sequential order. The raw data gathered from the interviews and the documents were assembled in themes and chronologically. Hereafter, the analysis was written in cooperation with the participant, which also be part of validating the story. This process is one crucial part to ensure that the story 'heard' is being reported accurately (Mills \& Gay, 2016). The results are reported in the following section within three points; the story of the non-native teacher, comparing the non-native teacher to the native teacher, and the notion of international English

\section{FINDINGS AND DISCUSSION}

\section{The teacher, the school, and the people}

The main character of this study

is an English teacher named Bruce (pseudonym). Bruce never imagines himself teaching to become an English teacher. Bruce grew up with a dream of becoming a police officer, shattered as he failed one of the tests. His last resort was to pursue his love for English. He then enrolled in one of the teacher training institutions majoring in English education. When I asked him how he becomes so affected by English, he brought himself to his four years old self. With a smile on his face, he told me how his aunt brought him to a cinema for his very first English film. He later added how he used to listen to his aunt's collection of English rock songs. His affection towards English seems to been planted up to his DNA.

The story continues to the time when he just graduated from the teaching institution. He then worked in a language school, which was founded by the same founder of his program back in the institution. There he met one NEST; he mentioned how he felt intimidated and inspired at the same time. He felt how he is not as fluent as the NEST in English, and how he saw himself as not a good as the NEST. He also believed that NEST teaches in a more interactive manner.

"I was like 'well, he is native;

his English must be better than

me'. I was nervous about speaking, about being honest during that session, I think I made plenty of slip tongue, stuttering, pausing because I think to intimidate myself. ... 'he is really good, I'm nothing compared him,' I doubt myself."

Motivated by their first encounter, Bruce tried to improve himself both in teaching and English proficiency. He changed his teaching style from what he called one-dimensional teaching, which distances himself to his students into more two-dimensional teaching with more interaction with his students. He believed that his teaching has become better after building such a relationship with his students.

The school he used to work with was newly established. He describes his job besides teaching was a social worker and part of the marketing team. He explains how the school often held free lessons in public places just to attract public attention to the school. Besides that, the school also makes use of the NEST as one of the marketing forces to attract new students. It can be seen in the brochures of the school. They explicitly mention 'speaking with native' in one brochure, along with pictures of the natives in another.

"Yes, we put the native in the brochure. It is working naturally."

A veteran in education founded the school itself. He was a teacher, Indonesian attaché for Australia, and researcher for World Bank. He can be considered an expert in education. His 
experiences working in Australia allow him to build a connection to some Australian who is willing to come to Indonesia, either for cultural exchanges or learning Indonesian. It is understandable how the school tried their best to promote their newly established school by hiring some of their acquaintances from Australia. However, most of the NEST are not a certified English teacher.

Another reason for this to happen is none other than the public, as the customer, see the white native speaker as the best English teacher. This fallacy comes from the era of colonization (Ruecker, 2011), where 'white' people seem to be more superior than the 'people of color'. Several studies have confirmed how the public see this preference based on skin color. The west is the best example of English, as English came from the west. Therefore, the teacher from the west is the best English teacher. (Holliday, 2005; Murtiana, 2011; Novianti, 2018; Quirk, 1985). It is supported by Bruce's story of a Russian missionary in West Kalimantan who is also teaching English. English is not the first language in Russia, and we can assume that the missionary is not a native speaker. Just because his Caucasian looks, the people of that area, trusted him to teach English.

There is some kind of entwining cycle between public and school. The public opinion of white teacher affects the school decision in hiring more native, the school's marketing of nativism build even stronger 'best teacher is white teacher' in public mind. There is no end to this point. As a result, the NNEST is often seen less prominent as an English teacher.

\section{The difference of two squares}

The difference of two squares is a mathematical terminology discussing two perfect squares, which can be factored into $(a+b)(a-b)$. Said that the native and the non-native teacher are the two perfect squares, they are two people who can teach English with their different language acquisition background. Both have their own strengths and weaknesses when it comes to teaching English to the speaker of other languages. Note that one binomial has a positive sign, and the other one has a negative sign. Let us say the first binomial is the native speaker teacher, who often seen as one with the plus point to teach English. While the second one, not necessarily negative, often seen as less prominent to teach English. Hence that a and $b$ supposedly have the same norm, say ' $a$ ' they speak English and ' $b$ ' they understand the function of the language. Nevertheless, one is seen to be more superior than the other.

Bruce shares his disappointment in this issue. He mentions how he needs to accomplish a series of training and test to be considered capable of teaching English. He also mentions his NEST partner did not even come from an education or teacher program.

"What I found out in my region, sometimes as long as you are a native speaker, you are deemed that you can teach English. Regardless of the lack of formal training to teach. But for me myself, it is not the case. You need formal training to teach. Just because you are a native speaker does not mean you have the right to teach. Because me myself, I need to have a bachelor degree, certification, and even IELTS to justify that I can teach English."

Besides, the job division is not equal. Bruce, as someone with a degree in education, is the one responsible for doing the paperwork, such as planning the teaching, processing the assessment and evaluation, and reporting it. The NEST is responsible for teaching language skills such as speaking and writing. It includes the assessment since the native speaker has more sense of naturality than a nonnative.

"For the sake of the school name, he (the school owner) will choose the native speaker." 
The identical result seen in Manara's (2013), wherein one teacher school, the NESTs are responsible for teaching language skill; meanwhile, the NNEST are responsible for teaching linguistics subject. Luckily, even though the NEST is not from an educational background, he willing to read and learn about assessment and grammar before teaching and assessing the students.

"Luckily, my partner was not a lazy person. He gave me a note on the students' weaknesses. Also, before he helped me, he prepares himself, as he read about grammar before he assesses and so on."

Another problem of non-teacher NEST is their lack of understanding in the learning plan. Bruce recalls the time when they run out time because the NEST planed an activity without well managed time management. $\mathrm{He}$, then, needs to supervise him even more than he usually did.

"Because of that, I tried to limit him from doing the idea because we need to stick to things. Because he is not from an education background, he did not know there is a set of regulations that a teacher needs to follow."

Another issue that cannot be neglected is how their wage differences. He understands how the native used with dollars might find their salary in rupiah too low. But if the wage is differentiated just because of the origin and not based on performance, Bruce believed that "there is something wrong with the system". As a result, Bruce needs to find side jobs to make some extra money.

"Yes, I need to do it because of the salary to cover my bills. To think about the differentiation of my salary with the native. Well, I don't know the exact numbers as it is confidential, but I know they are paid higher than me."
Besides the different treatments between Bruce and the NEST, public opinion also worries Bruce. Bruce worried the preference in NEST would result in NNEST to lose their job. Even though the NNEST come from teacher institution, not few of them are having low competences in teaching English. The public will prefer the native teacher even more than the local teacher. It will affect the other competent local teacher because the paradigm of a local teacher is not better than a native teacher.

"It worries me... it is going to put more challenges to the local teacher..., even though academically they are from the teacher training program. Their competence is far below."

The public opinion does matter, as the students also part of it. The students' preference in NEST is so apparent in Bruce's class. Bruce mentions how the students become more active in the class when the NEST presence. The NEST did not always present to the class, but when it comes, the class will become alive, and the students will actively asking the question. Although their questions more into the life of the NEST. Bruce often describes the NEST in the interviews as "more like an entertainer to the students". The students see the NEST as the celebrity that they have hardly seen in their day to day life.

"The students trust the native teacher. As they believe in anything he said as he is a native speaker... If we talk about respect as well, .... They respect the native teacher more than the Indonesian teacher." (emphasis added)

The students were in awe with their native teachers. They see him as some more than just a teacher. The word 'trust' showed Bruce's disappointment. As he mentions earlier, he needed to be certified in both language proficiency and pedagogically competent. However, he 
did not receive the same appreciation from his students.

The belief of nativism did not come solely from the public, and some educator also believes that native is the best language model (Ali, 2014; Manara, 2013). This belief is the exact opposite of what international English has in mind. The assessment rules are still in a lengthy discussion, and there seems no other choice but to follow the rules set by the native. As Quirk (1985) believed, the natives are the protector and rightful owners of the language. But this is not relevant to the current use of English. There is a bigger chance for non-native to speak in English with another non-native rather than with a native. Therefore, assessing the proficiency in fundamental norms is not necessary; the focus should be more on how the learners use language efficiently (Matsuda, 2006). What we need is an assessment which is more local friendly, so that the local teacher can contribute more.

Beside assessing, NNEST is much better to teach beginner students. Students' limited proficiency and NEST limited knowledge of the students' mother tongue and might affects the learning process (Gurkan \& Yuksel, 2012; Masrizal, 2013; Walkinshaw \& Oanh, 2014). But of the teacher have their strength and weaknesses. Therefore they should be treated equally. As Bruce mention, they should be assessed based on their performance, not where they came from, not their skin colour.

Moving towards international English

When asked about his opinion toward the notion of international English, Bruce eagerly accepts the notion. Bruce believes that

"English should be own by the one who speaks it, and you do not have to sound like a native."

Additionally, if the notion of international English fully implemented, he believes that it will provide a better chance for NNEST to compete with
NEST. The NNEST can teach English outside of their home country, treated equally as the NNEST, and even they can be paid the same as the NEST. He also believes that some NNEST might have better competence than a NEST.

"I know some local teacher who has better teaching competence than the bule, have a native accent. Some graduated from Australia or the UK. I think to affect their speaking ability." (emphasis added)

$\mathrm{He}$ also believed that some NEST might not accept the notion justly, some might reject it.

"I think the native speaker will tend to reject the notion. Because they think their privilege is taken away by the non-native."

Several studies seem to agree with Bruce's statement. A study by Hess (2009) found that only native speakers are allowed to teach English in South Korea $\&$ Taiwan. They have to show proof that clarifies their country of origin. Another unique case is a Chinese-American NEST is discriminated against in China, just because he does not look Caucasian. The NEST has a master degree in teaching English and even work experience in America, but because he looks local he is treated like a local non-native teacher (Greg, 2010). The discrimination is irrational, the teacher might able to change his nationality, but they will never be able to change his race.

Not only in non-English speaking countries, in the United States, but there are also constitutional policies that mandate the removal of the teacher with an accent from English as a Second Language class (Jordan, 2010; McKay \& Bokhorst-Heng, 2008). The discrimination towards NNEST and nonwhite NEST is real. The movement of international English is expected to address this issue. 


\section{CONCLUSION AND SUGGESTION}

The decision to hire more native teachers must not come that easy. The public preference is presumably the reason behind the decision. However, this reasoning does not seem to stop anytime soon. Schools will always try their best to promote their school in any manner, including using the word 'native-teacher' and pictures of natives in their advertisement. The preference must come from the general believes that a native teacher is the best English teacher. Besides that, being taught by native teachers seems like bragging the students' or parents' caste levels in public. This is severely affecting the NNEST. The 'discrimination' against the NNEST comes in the form of job division, job requirement, and wage. The only way for us to address this issue is by migrating towards international English. Nevertheless, this notion is still in a long fight both from the public eyes and the native eyes.

\section{REFERENCES}

Ali, F. (2014). Implementing EIL paradigm in ELT classrooms: Voices of experienced and preservice English language educators in Malaysia. In R. Marlina, \& R. A. Giri, The Pedagogy of English as an International Language (pp. 95109). Cham: Springer.

Braine, G. (2010). Nonnative speaker English teachers: Research, pedagogy, and professional growth. . New York: Routledge.

Cochran-Smith, M., \& Lytle, S. (2009). Inquiry as stance: Practitioner research for the next generation. New York: Teachers College Press.

Creswell, J. W. (2012). Educational research: Planning, conducting, and evaluating quantitative and qualitative research (4th Edition). Boston: Pearson Education Inc.

Davies, A. (2006). The native speaker in applied linguistics. In A. Davies, \& C. Elder, The Handbook of Applied Linguistics (pp. 431450). Oxford: Blackwell.

Gurkan, S., \& Yuksel, D. (2012). Evaluating the contributions of native and non-native teachers to an English Language Teaching program. Procedia-Social and Behavioral Sciences, 46, 29512958.

Hess, D. E. (2009). Controversy in the classroom: The democratic power of discussion. Routledge.

Holliday, A. (2005). The struggle to teach English as an international language. Oxford, England: Oxford University Press.

Jordan, M. (2010, April 30). Arizona grades teachers on fluency. The Wall Street Journal. Retrieved from http://online.wsj.com

Lasagabaster, D., \& Sierra, J. M. (2005). What do students think about the pros and cons of having a nativespeaker teacher? In E. Llurda, Non-native language teachers: Perceptions, challenges and contributions to the profession (pp. 217-242). New York: Springer.

Mahboob, A. (2003). Status of nonnative English speakers as ESL teachers in the United States (Unpublished doctoral dissertation). Indiana University, Bloomington: UMI Dissertation Services.

Manara, C. (2013). The Struggle of Moving towards EIL: Competing and Conflicting Narratives of Professionalism in an Indonesian Context. In N. T. Zacharias, \& C. Manara, Contextualizing the Pedagogy of English as an International Language: Issues and Tensions (pp. 150-167). 
Newcastle upon Tyne: Cambridge Scholars Publishing.

McKay, S. L. (2009). English as an international language: Where we are and where we need to go. English as an International Language Journal, 5, 27-54.

McKay, S. L., \& Bokhorst-Heng, W. D. (2017). International English in its sociolinguistic contexts: Towards a socially sensitive EIL pedagogy. Routledge.

Masrizal, M. (2013). Native vs non-native English teachers. Jurnal Ilmiah Didaktika, 13(2).

Matsuda, A. (2006). Negotiating ELT assumptions in EIL classrooms. In (Re-) Locating TESOL in an Age of Empire (pp. 158-170). Palgrave Macmillan, London.

Merriam, S. B. (2009). Qualitative research: A guide to design and implementation. San Francisco: Jossey-Bass.

Mills, G. E., \& Gay, L. R. (2016). Educational research: Competencies for analysis and applications. Boston: Pearson.

Murtiana, R. (2011). Student's perceptions of native speaker and non-native speaker teachers: Implication for teacher education. The 5th International Seminar: Teacher Education in the Era of World Englishes (pp. 29-42). Salatiga: Satya Wacana Christian University.

Muylaert, C. J., Sarubbi Jr., V., Gallo, P. R., Neto, M. L., \& Reis, A. O. (2014). Narrative interviews: an important resource in qualitative research. Revista da Escola de
Enfermagem da USP, 48(spe2), 184-189.

Novianti, A. (2018). Native versus nonnative English speaking teachers: an insight into Indonesian students' voices. Jurnal Pendididkan Bahasa dan Sastra, 18(1), 44-57. doi:DOI: 10.17509/bs_jpbsp.v18i1.12145

Quirk, R. (1985). The English language in a global context. In R. Quirk, \& $\mathrm{H}$. Widdowson, English in the world: Teaching and learning the language and literatures (pp. 16). Cambridge: Cambridge University Press.

Rajagopalan, K. (2005). Non-native speaker teachers of English and their anxieties: Ingredients for an experiment in action research. In E. (Llurda, Non-native language teacher: Perceptions, challenges, and contributions to the profession (pp. 283-303). New York: Springer.

Ruecker, T. (2011). Challenging the native and nonnative English speaker hierarchy in ELT: New directions from race theory. Critical Inquiry in Language Studies, 8(4), 400-422.

Walkinshaw, I., \& Oanh, D. H. (2014). Native and non-native English language teachers: Student perceptions in Vietnam and Japan. SAGE Open, 4(2), 1-9. doi:https://doi.org/10.1177/21582 44014534451 